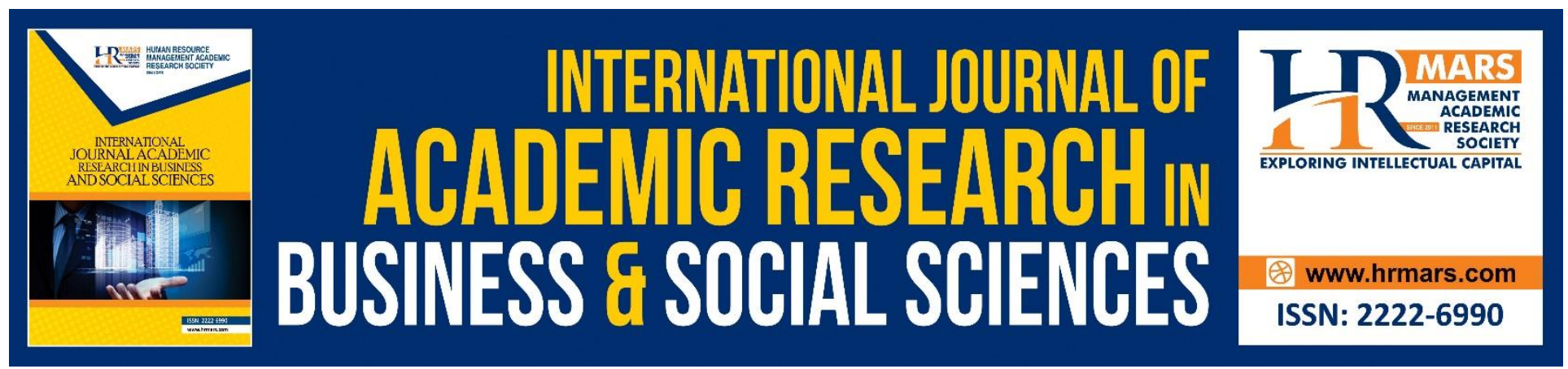

\title{
Influence on Internal Control through Digitalization of Assets: A Study on Ministry of Interior, UAE
}

Ahmed Khamis Ali Saeed Alkaabi, Joseph Adaikalam, Asif Mahbub Karim, Oo Yu Hock, Mohammad Imtiaz Hossain

To Link this Article: http://dx.doi.org/10.6007/IJARBSS/v10-i2/6874

DOI:10.6007/IJARBSS/v10-i2/6874

Received: 20 December 2019, Revised: 10 January 2020, Accepted: 21 January 2020

Published Online: 03 February 2020

In-Text Citation: (Alkaabi et al., 2020)

To Cite this Article: Alkaabi, A. K. A. S., Adaikalam, J., Karim, A. M., \& Hossain, O. Y. H. M. I. (2020). Influence on Internal Control through Digitalization of Assets: A Study on Ministry of Interior, UAE. International Journal of Academic Research in Business and Social Sciences, 10(2), 83-102.

Copyright: (C) 2020 The Author(s)

Published by Human Resource Management Academic Research Society (www.hrmars.com)

This article is published under the Creative Commons Attribution (CC BY 4.0) license. Anyone may reproduce, distribute, translate and create derivative works of this article (for both commercial and non-commercial purposes), subject to full attribution to the original publication and authors. The full terms of this license may be seen at: http://creativecommons.org/licences/by/4.0/legalcode

Vol. 10, No. 2, 2020, Pg. $83-102$

Full Terms \& Conditions of access and use can be found at http://hrmars.com/index.php/pages/detail/publication-ethics 


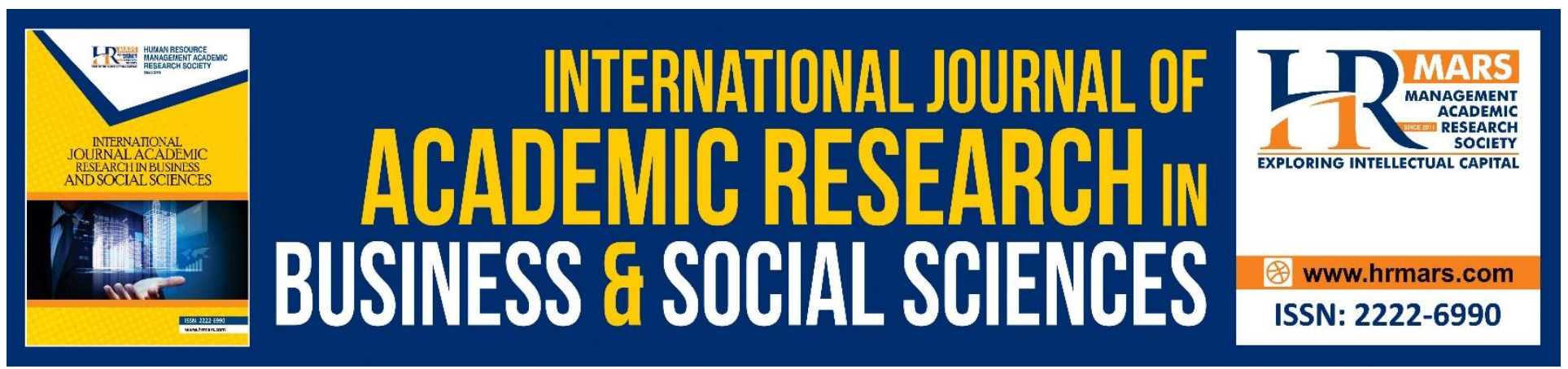

\title{
Influence on Internal Control through Digitalization of Assets: A Study on Ministry of Interior, UAE
}

\section{${ }^{1}$ Ahmed Khamis Ali Saeed Alkaabi, ${ }^{2}$ Professor Joseph Adaikalam, ${ }^{3}$ Dr Asif Mahbub Karim, ${ }^{4}$ Dr Oo Yu Hock, ${ }^{5}$ Mohammad Imtiaz Hossain}

${ }^{1} \mathrm{PhD}$ Research Fellow, Binary University of Management \& Entrepreneurship, Malaysia, ${ }^{2}$ Founder and Executive Chairman, Binary University of Management \& Entrepreneurship, Malaysia, ${ }^{3}$ Dean \& Associate Professor, Binary Graduate School, Binary University of Management \& Entrepreneurship,

Malaysia, ${ }^{4}$ Professor, Asia e University (AeU), Malaysia, ${ }^{5} \mathrm{MSc}$ in Business Economics, Universiti

Putra Malaysia, Malaysia

\begin{abstract}
Fixed assets management through digitalization have been always been a matter of concern for public organization, especially organization as strategic and important like Ministry of Interior, in the United Arab Emirates. Since there are huge assets procurement, its management and control keeping has been a daunting task always. The purpose of this research is to evaluate the influence of internal control through assets management's digitalization. To carry on with the research work a survey questionnaire was designed. A structured questionnaire was used to collect data and SPSS was used to analyse them.

From the finding of the survey it was observed that the pace of digitalization was not so fast moreover the control on the assets tracking system at times was difficult as the ministry deals with very sophisticated tangible equipment's. Well, after examining the evaluation of fixed assets management through digitalization, a study on ministry of interior in UAE - the first objective of the study, it is seen that yet the application of the assets management through digitalization is not in that level so the performance is very poor. This study may inform managers of the importance of understanding the technology are a fundamental part of the business that requires its strategy. It may also have implications for the organization's mentality towards internal factors concerning the technical systems.
\end{abstract}

Keywords: Internal Control, Digitalization, Fixed Assets Management, UAE.

\section{Introduction}

Asset Management is not a new field that has suddenly come out of nowhere; asset management activities have been carried out since utilizing capital assets started, such as power plants, ships, 
INTERNATIONAL JOURNAL OF ACADEMIC RESEARCH IN BUSINESS AND SOCIAL SCIENCES Vol. 10, No. 2, Feb, 2020, E-ISSN: 2222-6990 @ 2020 HRMARS

buildings, or any kind of production assets. However, changes in technology and business environment mean that asset management is more important that before and has a new focus, among other reasons, because growing turbulence of markets, globalization and increasing competition, pressure for higher profitability, so Asset Management has become a new discipline and gradually has gained the attention in many places in the world.

Asset Management process is the set of processes aligning the development, operation and maintenance of assets, so as to meet the desired requirements and objectives of the shareholders in the organization. Asset Management is a systematic process of maintaining, upgrading and operating assets, combining engineering principles with sound business practice and economic rationale, and providing tools to facilitate a more organized and flexible approach to making the decisions necessary to achieve the public's expectations (Davenport, \& Westerman, 2018).

Assets are classified into two categories: tangible and intangible. Tangible assets are assets that one can touch, hold, or feel. Typically called fixed assets in accounting literature, tangible assets are the physical things that a business uses in the production of goods and services. They constitute the production facilities, buildings, equipment, and vehicles. These operational assets of a business include furniture, computers, and similar items not used up within a year. Intangible assets are primarily financing items: stocks, bonds, mortgages, etc.

A fixed asset management life-cycle consists of a set of procedures that align with the enhancement, operation, maintenance of fixed assets, in order to meet the demands and objectives of the business decision makers. The scope of fixed assets management is often broad within an institute due to connection between its internal factors such as human resources, finance, technology, operation, production, information technology and management, as the same time external factors such as governance and external environmental. Fixed asset management via digitalization is aim to optimize the management processes, modelling initiatives should be implemented.

Information of fixed asset management enhances the effectiveness of decision-making process in the organization. It captured in advances and abstract level within the scope of organization workflow, which used as an executable guideline for implement the fixed asset management decision process in practice. Moreover, it can be used as system which incorporated with plenty of information and workflow process. It is able to support the automation workflow of such a process in a more elaborated way.

Digitization is the process of creating electronic resources from your physical assets, and has rapidly evolved into one of the most recognized forms of organizational efficiency for companies today, and tomorrow. Proper digitization is more than just scanning and storing documents in an electronic format. Digitization is a strategy that involves systems, tools and technologies, organization including: meta-data, cataloging and captioning, and most importantly, the right Digital Asset Management (DAM) system (Matt, Hess, \& Benlian, 2015). The smart adoption of technology and exploitation of the data it generates can help companies reinvent their business model, achieve major operational and cost efficiencies, and become more relevant to their customers (Lee, \& Shin, 2018).

Essaides (2019) noted from a Hackett Group's recent study “Internal Controls in the Age of Disruption Study" (2019) that expects a significant increase in digitalization on asset management. For example, they project that the adoption of advanced analytics solutions will more than double over the next 12 to 24 months. 

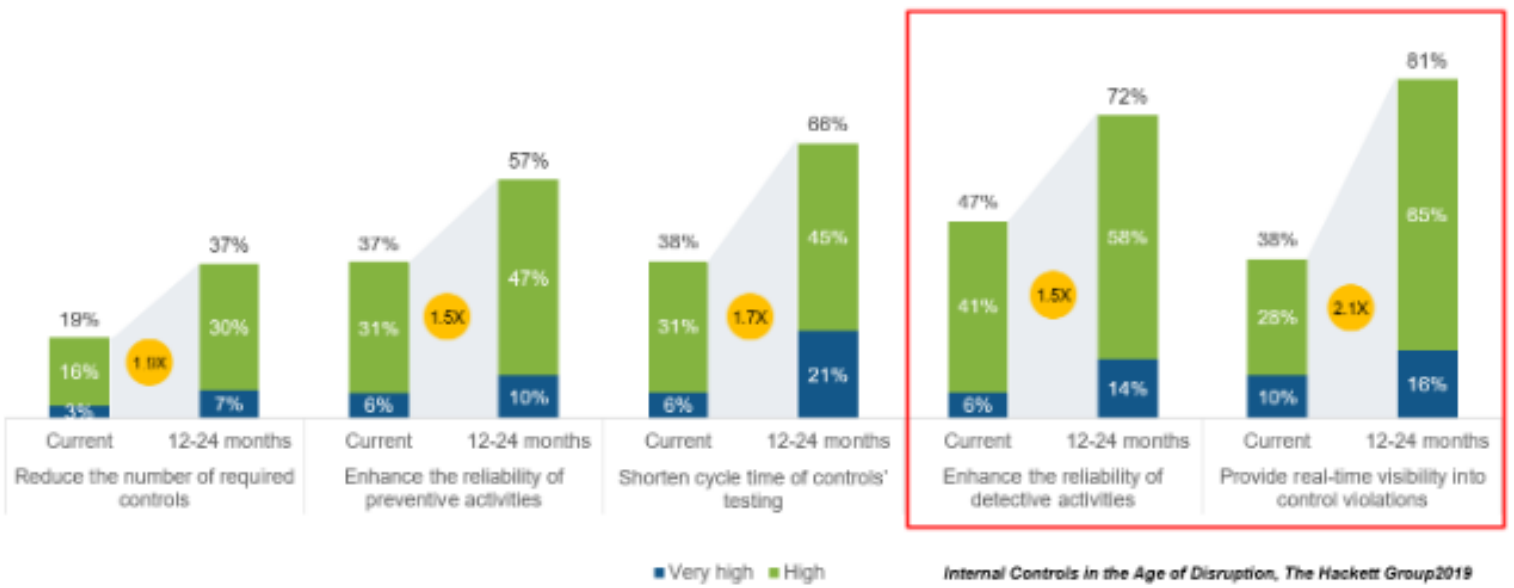

While UAE companies lead their GCC peers in going digital, they must do more to engage consumers in their market, who are among the most tech-savvy in the world, and stay relevant in an age of disruption. The digitization of the Saudi economy has for the past decade or more been led by individual ministries and their "digital arms", which they have either developed themselves or with companies operating in related fields. Ministry of UAE is working in the field of information security before expanding into wider range of IT support services.

\section{Literature Review}

Managing effective asset management is not an alternative for an organization if it is to achieve and keep a competitive situation. Understanding and rapidly communicating the complaints and demands of customers to internal managers then can ensure that these demands are met rapidly and accurately, are essential and significant to every organization. Automated asset management helps enhance the organization's response time and efficient the accuracy of the management and process that result in the products and services that customer's satisfaction. Capturing the competitive race depends on having the proficiency demanded to compete and the ability to express that competence to achieve maximum competition advantage. Effective and useful automated workflow management of knowledge and information is the key factor to unlocking the capability and knowledge that resides in every organization.

There are solutions that help create the right structures and consistency in the content used for branding: Digital Asset Management (DAM). Data can be stored, managed, found, retrieved, shared and sent using DAM software. Individual media content is described by individual metadata, which may vary depending on the needs of the system or target groups, such as designers or users. In this way, the data supply of numerous channels can be designed intelligently (Moran, 2015). Digital assets are the digital ownership of all values. This is the most accurate definition, but we may not be clear enough to understand. In general, digital assets can be classified in two basic categories (Björling, 2015):

- $\quad$ Limited audited digital assets, such as PayPal's digital dollars or central bank digital assets. It's hard to audit these digital assets, which means you can't confirm the authenticity of their processes; you can only choose who believes in managing those assets. 
- $\quad$ Token: Its accounting is more transparent because some processes can be audited. Encrypted tokens are accounting units used to represent a numerical balance with a specific value, and the ownership of the token is evidenced by certain cryptographic mechanisms, such as digital signatures. Many businesses are well down the path to digitizing their most important assets. Healthcare facilities and educational institutions are easy examples to point out; they continue their inexorable shift toward electronic records and books. The aim of digitization is straightforward - to make information easier to access, and leverage-able by the broader organization for business advantage. Digital asset management (DAM) has been referred to by a variety of names that often are used interchangeably, such as Enterprise Content Management (ECM), Digital Content Management (DCM), Digital Media Management (DMM), Media Asset Management (MAM), and Rich Media Asset Management (RMAM) (Alkaabi, Karim, Hossain, \& Nasiruzzaman, 2019)

DAM software enables consistent branding through efficient data storage and coordination of individual assets. In-house, flexibility and mobility are promoted by giving users secure access to mission-critical assets, whether they are querying them from the desktop or mobile. Another advantage: A DAM usually has a feature for license management, so that one's own content can be legally reused - even when put together again. DAM solutions also provide an overview of all digital data types. The bottom line is that production delays and thus costs are avoided by distributing tasks to internal and external teams. As a result, there is more transparency in terms of changes, annotations and approvals, which are reproducible by system (Matt, Hess, \& Benlian, 2015).

At present, the blockchain application areas being developed in China include: the circulation network of digital assets, the digitization of physical assets and interests, network distribution, transactions, delivery, global transparent supply chain and genuine and false verification of goods, smart contracts, big data, Internet of Things and cloud computing. With tools like robotic process automation (RPA) and Al-enabled analytics, they are beginning to automate compliance monitoring and remediation activities. They are also using machine learning solutions to detect suspicious activities, identify emerging control points, and learn from experience on an ongoing basis (Jonsdottir, et al., 2017).

To digitize things and people is a different story. The digitization of people allows enterprises to leverage knowledge - tribal and otherwise - for faster and more accurate decision-making; to make information easier to access through online records and real-time collaboration; and secure an intellectual legacy that perpetuates the business. Digitizing your people allows a company to make any desk less worker as smart as the smartest individual, unhindered by geographic location, or timezone (Gomber, et al., 2017).

At the regional level, the 2018 Global Digital Competitiveness Report presents a gap in digitization in general, and despite the clear leadership of the UAE and its improved performance in the various factors of the technology index, particularly technology, the gap between the UAE and the rest of the Arab countries is very wide, Followed by Qatar in 28th place, and then the gap widens further to Saudi Arabia in 42nd place, and Jordan in 45th place with improvement of more than ten ranks. 
INTERNATIONAL JOURNAL OF ACADEMIC RESEARCH IN BUSINESS AND SOCIAL SCIENCES Vol. 10, No. 2, Feb, 2020, E-ISSN: 2222-6990 @ 2020 HRMARS

\section{Conceptual Framework}

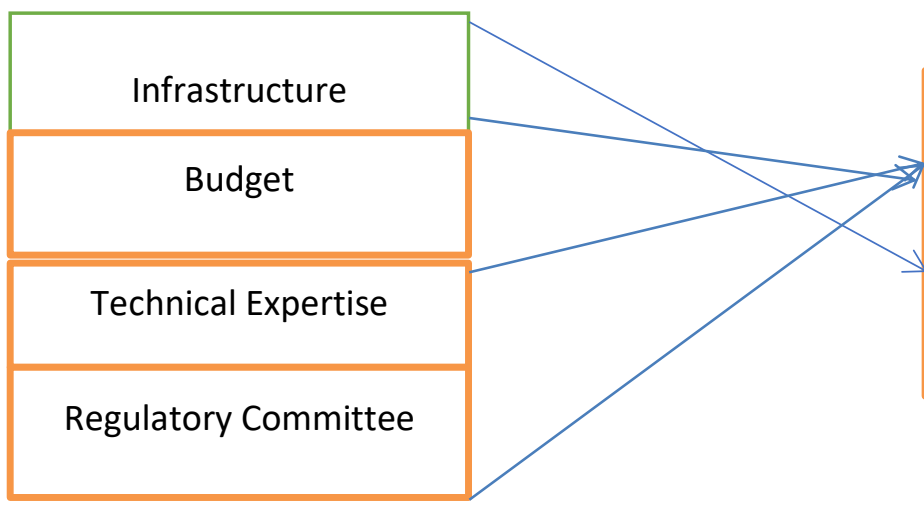

Fixed Assets Management through Digitalization

Source: Author

\section{Research Objectives}

The specific objective of the research is,

* To analyse the performance of fixed assets management through digitalization of Ministry of Interior, UAE

The other objectives of the research are,

* To study on the impact of digitalization of fixed assets management in MOI

* To examine elements involve in the automation processes

* To make recommendation to improve fixed assets management performance via digitalization

\section{Methodology}

A quantitative methodology is used to assess the trust of the system that leads to its adoption. The research was conducted using self-administered questionnaires. A structured questionnaire was prepared after consultation guides, experts in the field, and after going through review of relevant literature. The questionnaire designed in this study is 5 Likert Scale. Questions of Independent variables were utilizing on a Likert scale ranging from $1=$ strongly disagree to $6=$ strongly agree and some use $5=$ much better off, $4=$ somehow better off; 3 =about the same; $2=$ somehow worse off; $1=$ much worse off. SPSS used to analyse the data. In total, 180 questionnaires were administered to the members of the public. Out of the 180 questionnaires that were administered 165 were returned. From the numbers returned, 15 were either incomplete or improperly filled which rendered them useless for analysis. Therefore, only 150 were considered for analysis. 
INTERNATIONAL JOURNAL OF ACADEMIC RESEARCH IN BUSINESS AND SOCIAL SCIENCES Vol. 10, No. 2, Feb, 2020, E-ISSN: 2222-6990 ¿ 2020 HRMARS

\section{Data Analysis and Findings}

\section{Demographics}

\begin{tabular}{|c|c|c|c|c|c|}
\hline \multicolumn{6}{|c|}{ Gender } \\
\hline & & Frequency & Percent & Valid Percent & $\begin{array}{l}\text { Cumulative } \\
\text { Percent }\end{array}$ \\
\hline \multirow{3}{*}{ Valid } & Male & 61 & 40.7 & 40.7 & 40.7 \\
\hline & Female & 89 & 59.3 & 59.3 & 100.0 \\
\hline & Total & 150 & 100.0 & 100.0 & \\
\hline
\end{tabular}

\begin{tabular}{|l|l|l|l|l|l|}
\hline \multicolumn{2}{|l|}{ Age in year } & Frequency & Percent & Valid Percent & Cumulative Percent \\
\hline \multirow{4}{*}{ Valid } & 20 to 29 & 23 & 15.3 & 15.3 & 15.3 \\
\cline { 2 - 6 } & 30 to 39 & 76 & 50.7 & 50.7 & 66.0 \\
\cline { 2 - 6 } & 40 to 49 & 46 & 30.7 & 30.7 & 96.7 \\
\cline { 2 - 6 } & 50 to 59 & 5 & 3.3 & 3.3 & 100.0 \\
\hline & Total & 150 & 100.0 & 100.0 & \\
\hline
\end{tabular}

Education Background

\begin{tabular}{|l|lllll|}
\hline \multicolumn{1}{|c}{} & Frequency & Percent & Valid Percent & Cumulative Percent \\
\hline Valid & Diploma & 60 & 40.0 & 40.0 & 40.0 \\
& Undergraduate & 68 & 45.3 & 45.3 & 85.3 \\
& Postgraduate & 21 & 14.0 & 14.0 & 99.3 \\
& Others & 1 & .7 & .7 & 74.5 \\
\cline { 2 - 6 } & Total & 150 & 100.0 & 100.0 & 100.0 \\
\hline
\end{tabular}

\section{Infrastructure}

Familiarity and Expertise with The Technologies Relating Asset Management

\begin{tabular}{|c|c|c|c|c|c|}
\hline & & Frequency & Percent & Valid Percent & Cumulative Percent \\
\hline \multirow[t]{4}{*}{ Valid } & so so & 7 & 4.7 & 4.7 & 4.7 \\
\hline & Better & 34 & 22.7 & 22.7 & 27.3 \\
\hline & Excellent & 109 & 72.7 & 72.7 & 100.0 \\
\hline & Total & 150 & 100.0 & 100.0 & \\
\hline
\end{tabular}


INTERNATIONAL JOURNAL OF ACADEMIC RESEARCH IN BUSINESS AND SOCIAL SCIENCES Vol. 10, No. 2, Feb, 2020, E-ISSN: 2222-6990 (C) 2020 HRMARS

Your Involvement in Implementing Methods of Managing and Preserving Digitalization

\begin{tabular}{|ll|l|l|l|l|}
\hline & & Frequency & Percent & Valid Percent & Cumulative Percent \\
\hline Valid & Poor & 1 & .7 & .7 & .7 \\
So So & 3 & 2.0 & 2.0 & 2.7 \\
Better & 91 & 60.7 & 60.7 & 63.3 \\
Excellent & 55 & 36.7 & 36.7 & 100.0 \\
\hline Total & 150 & 100.0 & 100.0 & \\
\hline
\end{tabular}

Ability of Your Department to Organize The E-Data

\begin{tabular}{|c|c|c|c|c|c|}
\hline & & Frequency & Percent & Valid Percent & $\begin{array}{l}\text { Cumulative } \\
\text { Percent }\end{array}$ \\
\hline \multirow[t]{5}{*}{ Valid } & Poor & 1 & .7 & .7 & .7 \\
\hline & so so & 27 & 18.0 & 18.0 & 18.7 \\
\hline & Better & 75 & 50.0 & 50.0 & 68.7 \\
\hline & Excellent & 47 & 31.3 & 31.3 & 100.0 \\
\hline & Total & 150 & 100.0 & 100.0 & \\
\hline
\end{tabular}

Top management have full support on arranging trainings

\begin{tabular}{|ll|l|l|l|l|}
\hline & Frequency & Percent & Valid Percent & $\begin{array}{l}\text { Cumulative } \\
\text { Percent }\end{array}$ \\
\hline Valid & strongly disagree & 3 & 2.0 & 2.0 & 2.0 \\
& Disagree & 5 & 3.3 & 3.3 & 5.3 \\
Neutral & 16 & 10.7 & 10.7 & 16.0 \\
Agree & 67 & 44.7 & 44.7 & 60.7 \\
strongly agree & 59 & 39.3 & 39.3 & 100.0 \\
Total & 150 & 100.0 & 100.0 & \\
\hline
\end{tabular}


INTERNATIONAL JOURNAL OF ACADEMIC RESEARCH IN BUSINESS AND SOCIAL SCIENCES Vol. 10, No. 2, Feb, 2020, E-ISSN: 2222-6990 (C) 2020 HRMARS

\section{Regulatory Committee}

Degree of Involvement by Regulatory Committee

\begin{tabular}{|ll|l|l|l|l|}
\hline & & Frequency & Percent & Valid Percent & Cumulative Percent \\
\hline Valid & Worst & 1 & .7 & .7 & .7 \\
& Poor & 3 & 2.0 & 2.0 & 2.7 \\
so so & 32 & 21.3 & 21.3 & 24.0 \\
Better & 80 & 53.3 & 53.3 & 77.3 \\
Excellent & 34 & 22.7 & 22.7 & 100.0 \\
Total & 150 & 100.0 & 100.0 & \\
\hline
\end{tabular}

Departmental Communication with regulatory committee for Digitalization

\begin{tabular}{|ll|l|l|l|l|}
\hline & & Frequency & Percent & Valid Percent & Cumulative Percent \\
\hline Valid & Poor & 5 & 3.3 & 3.3 & 3.3 \\
& so so & 27 & 18.0 & 18.0 & 21.3 \\
& Better & 63 & 42.0 & 42.0 & 63.3 \\
& excellent & 55 & 36.7 & 36.7 & 100.0 \\
& Total & 150 & 100.0 & 100.0 & \\
\hline
\end{tabular}

Employing Regulatory committee increase Efficiency

\begin{tabular}{|c|c|c|c|c|c|}
\hline & & Frequency & Percent & Valid Percent & $\begin{array}{l}\text { Cumulative } \\
\text { Percent }\end{array}$ \\
\hline \multirow[t]{5}{*}{ Valid } & strongly disagree & 1 & .7 & .7 & .7 \\
\hline & Neutral & 9 & 6.0 & 6.0 & 6.7 \\
\hline & Agree & 39 & 26.0 & 26.0 & 32.7 \\
\hline & strongly agree & 101 & 67.3 & 67.3 & 100.0 \\
\hline & Total & 150 & 100.0 & 100.0 & \\
\hline
\end{tabular}


INTERNATIONAL JOURNAL OF ACADEMIC RESEARCH IN BUSINESS AND SOCIAL SCIENCES Vol. 10, No. 2, Feb, 2020, E-ISSN: 2222-6990 (C) 2020 HRMARS

\section{Technical Expertise}

Repair and maintenance department are properly functional

\begin{tabular}{|c|c|c|c|c|c|}
\hline & & Frequency & Percent & Valid Percent & $\begin{array}{l}\text { Cumulative } \\
\text { Percent }\end{array}$ \\
\hline \multirow{5}{*}{ Valid } & Disagree & 4 & 2.7 & 2.7 & 2.7 \\
\hline & Neutral & 21 & 14.0 & 14.0 & 16.7 \\
\hline & Agree & 68 & 45.3 & 45.3 & 62.0 \\
\hline & strongly agree & 57 & 38.0 & 38.0 & 100.0 \\
\hline & Total & 150 & 100.0 & 100.0 & \\
\hline
\end{tabular}

Have adequate safeguarding expertise to protect fixed assets from theft and fire

\begin{tabular}{|c|c|c|c|c|c|}
\hline & & Frequency & Percent & Valid Percent & $\begin{array}{l}\text { Cumulative } \\
\text { Percent }\end{array}$ \\
\hline \multirow[t]{6}{*}{ Valid } & strongly disagree & 1 & .7 & .7 & .7 \\
\hline & Disagree & 1 & .7 & .7 & 1.3 \\
\hline & Neutral & 11 & 7.3 & 7.3 & 8.7 \\
\hline & Agree & 45 & 30.0 & 30.0 & 38.7 \\
\hline & strongly agree & 92 & 61.3 & 61.3 & 100.0 \\
\hline & Total & 150 & 100.0 & 100.0 & \\
\hline
\end{tabular}

\section{Budget}

Budget are sufficient

\begin{tabular}{|c|c|c|c|c|c|}
\hline & & Frequency & Percent & Valid Percent & $\begin{array}{l}\text { Cumulative } \\
\text { Percent }\end{array}$ \\
\hline \multirow[t]{6}{*}{ Valid } & strongly disagree & 3 & 2.0 & 2.0 & 2.0 \\
\hline & Disagree & 3 & 2.0 & 2.0 & 4.0 \\
\hline & Neutral & 11 & 7.3 & 7.3 & 11.3 \\
\hline & Agree & 42 & 28.0 & 28.0 & 39.3 \\
\hline & strongly agree & 91 & 60.7 & 60.7 & 100.0 \\
\hline & Total & 150 & 100.0 & 100.0 & \\
\hline
\end{tabular}


INTERNATIONAL JOURNAL OF ACADEMIC RESEARCH IN BUSINESS AND SOCIAL SCIENCES Vol. 10, No. 2, Feb, 2020, E-ISSN: 2222-6990 @ 2020 HRMARS

Budget is properly utilized

\begin{tabular}{|c|c|c|c|c|c|}
\hline & & Frequency & Percent & Valid Percent & $\begin{array}{l}\text { Cumulative } \\
\text { Percent }\end{array}$ \\
\hline \multirow[t]{6}{*}{ Valid } & strongly disagree & 2 & 1.3 & 1.3 & 1.3 \\
\hline & Disagree & 7 & 4.7 & 4.7 & 6.0 \\
\hline & Neutral & 6 & 4.0 & 4.0 & 10.0 \\
\hline & Agree & 84 & 56.0 & 56.0 & 66.0 \\
\hline & strongly agree & 51 & 34.0 & 34.0 & 100.0 \\
\hline & Total & 150 & 100.0 & 100.0 & \\
\hline
\end{tabular}

Digitalization allow Organization to control system over fixed asset

\begin{tabular}{|c|c|c|c|c|c|}
\hline & & Frequency & Percent & Valid Percent & $\begin{array}{l}\text { Cumulative } \\
\text { Percent }\end{array}$ \\
\hline \multirow[t]{5}{*}{ Valid } & Disagree & 3 & 2.0 & 2.0 & 2.0 \\
\hline & Neutral & 13 & 8.7 & 8.7 & 10.7 \\
\hline & Agree & 34 & 22.7 & 22.7 & 33.3 \\
\hline & strongly agree & 100 & 66.7 & 66.7 & 100.0 \\
\hline & Total & 150 & 100.0 & 100.0 & \\
\hline
\end{tabular}

Internal influence is important for digitization over fixed assets

\begin{tabular}{|ll|l|l|l|l|}
\hline & Frequency & Percent & Valid Percent & $\begin{array}{l}\text { Cumulative } \\
\text { Percent }\end{array}$ \\
\hline Valid & strongly disagree & 3 & 2.0 & 2.0 & 2.0 \\
& Disagree & 4 & 2.7 & 2.7 & 4.7 \\
Neutral & 6 & 4.0 & 4.0 & 8.7 \\
Agree & 89 & 59.3 & 59.3 & 68.0 \\
strongly agree & 48 & 32.0 & 32.0 & 100.0 \\
Total & 150 & 100.0 & 100.0 & \\
\hline
\end{tabular}


INTERNATIONAL JOURNAL OF ACADEMIC RESEARCH IN BUSINESS AND SOCIAL SCIENCES Vol. 10, No. 2, Feb, 2020, E-ISSN: 2222-6990 @ 2020 HRMARS

\section{Tests of Normality}

\begin{tabular}{|l|l|l|l|l|l|l|}
\hline & \multicolumn{4}{l|}{ Kolmogorov-Smirnova $^{\text {a }}$} & \multicolumn{4}{l|}{ Shapiro-Wilk } \\
\cline { 2 - 7 } & Statistic & Df & Sig. & Statistic & df & Sig. \\
\hline $\begin{array}{l}\text { Fixed Assets } \\
\begin{array}{l}\text { Management } \\
\text { through } \\
\text { Digitalization }\end{array}\end{array}$ & .149 & 150 & .000 & .948 & 150 & .000 \\
\hline
\end{tabular}

a. Lilliefors Significance Correction

\begin{tabular}{|l|l|l|l|l|l|l|}
\hline & \multicolumn{3}{|l|}{ Kolmogorov-Smirnov ${ }^{\text {a }}$} & \multicolumn{3}{l|}{ Shapiro-Wilk } \\
\cline { 2 - 8 } & Statistic & df & Sig. & Statistic & df & Sig. \\
\hline Infrastructure & .174 & 150 & .000 & .865 & 150 & .000 \\
\hline
\end{tabular}

a. Lilliefors Significance Correction

\begin{tabular}{|c|l|l|l|l|l|l|}
\hline \multirow{2}{*}{} & \multicolumn{3}{|l|}{ Kolmogorov-Smirnov $^{\mathrm{a}}$} & \multicolumn{3}{l|}{ Shapiro-Wilk } \\
\cline { 2 - 7 } & Statistic & Df & Sig. & Statistic & df & Sig. \\
\hline $\begin{array}{l}\text { Technical } \\
\text { Expertise }\end{array}$ & .258 & 150 & .000 & .742 & 150 & .000 \\
\hline
\end{tabular}

a. Lilliefors Significance Correction

\begin{tabular}{|l|l|l|l|l|l|l|}
\hline \multirow{2}{*}{} & \multicolumn{4}{l|}{ Kolmogorov-Smirnov $^{\text {a }}$} & \multicolumn{3}{l|}{ Shapiro-Wilk } \\
\cline { 2 - 7 } & Statistic & Df & Sig. & Statistic & Df & Sig. \\
\hline Regulatory Committee & .189 & 150 & .000 & .908 & 150 & .000 \\
\hline
\end{tabular}

a. Lilliefors Significance Correction

From normality table we can see that for Kolmogorov-Smirnov and Shapiro-Wilk test the $p$ value is exactly 0.00 which means the test is significant and not follows normal distribution. And also from histogram, normal Q-Q plot and detrended normal Q-Q plot, the test statistic not follows the normal distribution. 
INTERNATIONAL JOURNAL OF ACADEMIC RESEARCH IN BUSINESS AND SOCIAL SCIENCES Vol. 10, No. 2, Feb, 2020, E-ISSN: 2222-6990 @ 2020 HRMARS

\section{Mann-Whitney Test}

\begin{tabular}{|c|c|c|c|c|}
\hline & $\begin{array}{l}\text { sex/gen } \\
\text { der }\end{array}$ & $\mathrm{N}$ & Mean Rank & Sum of Ranks \\
\hline \multirow{2}{*}{\multicolumn{2}{|c|}{$\begin{array}{l}\text { Fixed } \quad \text { Assets Male } \\
\text { Management through female }\end{array}$}} & 61 & 74.15 & 4523.00 \\
\hline & & 89 & 76.43 & 6802.00 \\
\hline & Total & 150 & & \\
\hline \multirow[t]{3}{*}{ Infrastructure } & male & 61 & 76.25 & 4651.50 \\
\hline & female & 89 & 74.98 & 6673.50 \\
\hline & Total & 150 & & \\
\hline \multirow[t]{3}{*}{ Technical Expertise } & male & 61 & 74.91 & 4569.50 \\
\hline & female & 89 & 75.90 & 6755.50 \\
\hline & Total & 150 & & \\
\hline \multicolumn{2}{|c|}{ Regulatory Committee male } & 61 & 82.09 & 5007.50 \\
\hline & female & 89 & 70.98 & 6317.50 \\
\hline & Total & 150 & & \\
\hline \multirow[t]{3}{*}{ Budget } & male & 61 & 83.54 & 5096.00 \\
\hline & female & 89 & 69.99 & 6229.00 \\
\hline & Total & 150 & & \\
\hline
\end{tabular}

Test Statistics ${ }^{\mathrm{a}}$

\begin{tabular}{|l|l|l|l|l|l|}
\hline & $\begin{array}{l}\text { Asset } \\
\text { Management } \\
\text { Digitalization }\end{array}$ & $\begin{array}{l}\text { Infrastructur } \\
\text { e }\end{array}$ & $\begin{array}{l}\text { Technical } \\
\text { Expertise }\end{array}$ & $\begin{array}{l}\text { Regulatory } \\
\text { Committee }\end{array}$ & Budget \\
\hline Mann-Whitney U & 2632.000 & 2668.500 & $2.678 \mathrm{E} 3$ & 2312.500 & $2.224 \mathrm{E} 3$ \\
Wilcoxon W & 4523.000 & 6673.500 & $4.570 \mathrm{E} 3$ & 6317.500 & $6.229 \mathrm{E} 3$ \\
Z & -.321 & -.180 & -.147 & -1.578 & -2.189 \\
Asymp. Sig. (2-tailed) & .748 & .857 & .883 & .115 & .029 \\
\hline
\end{tabular}

a. Grouping Variable: sex/gender

The corresponding $p$ - value of the test statistic for the only Budget has been observed to be 0.029 which is less than 0.05 . It can thus be concluded that there is no difference between the Infrastructure Technical Expertise, Regulatory Committee, except for the Budget, where the people who are below 30 years encounter more challenges than other age groups. This can be explained that lack of Budget, as a challenge, is primarily considered by the people who are below 30 years as the mean rank of 69.99 which is lower than the mean rank of other age group. 
INTERNATIONAL JOURNAL OF ACADEMIC RESEARCH IN BUSINESS AND SOCIAL SCIENCES Vol. 10, No. 2, Feb, 2020, E-ISSN: 2222-6990 @ 2020 HRMARS

\section{Kruskal-Wallis Test}

\begin{tabular}{|c|c|c|c|}
\hline & sex/gender & $N$ & Mean Rank \\
\hline $\begin{array}{l}\text { Fixed Asset } \\
\text { Management } \\
\text { through } \\
\text { Digitalization } \\
\end{array}$ & $\begin{array}{l}\text { male } \\
\text { female } \\
\text { Total }\end{array}$ & $\begin{array}{l}61 \\
89 \\
150\end{array}$ & $\begin{array}{l}74.15 \\
76.43\end{array}$ \\
\hline Infrastructure & $\begin{array}{l}\text { male } \\
\text { female } \\
\text { Total }\end{array}$ & $\begin{array}{l}61 \\
89 \\
150\end{array}$ & $\begin{array}{l}76.25 \\
74.98\end{array}$ \\
\hline Technical Expertise & $\begin{array}{l}\text { male } \\
\text { female } \\
\text { Total }\end{array}$ & $\begin{array}{l}61 \\
89 \\
150\end{array}$ & $\begin{array}{l}74.91 \\
75.90\end{array}$ \\
\hline $\begin{array}{l}\text { Regulatory } \\
\text { Committee }\end{array}$ & $\begin{array}{l}\text { male } \\
\text { female } \\
\text { Total }\end{array}$ & $\begin{array}{l}61 \\
89 \\
150\end{array}$ & $\begin{array}{l}82.09 \\
70.98\end{array}$ \\
\hline Budget & $\begin{array}{l}\text { male } \\
\text { female } \\
\text { Total }\end{array}$ & $\begin{array}{l}61 \\
89 \\
150\end{array}$ & $\begin{array}{l}83.54 \\
69.99\end{array}$ \\
\hline
\end{tabular}

Test Statistics ${ }^{a, b}$

\begin{tabular}{|l|l|l|l|l|l|}
\hline & $\begin{array}{l}\text { Asset } \\
\text { Management } \\
\text { Digitalization }\end{array}$ & $\begin{array}{l}\text { Infrastructur } \\
\text { e }\end{array}$ & $\begin{array}{l}\text { Technical } \\
\text { Expertise }\end{array}$ & $\begin{array}{l}\text { Regulatory } \\
\text { Committee }\end{array}$ & Budget \\
\hline Chi-Square & .103 & .032 & .022 & 2.489 & 4.794 \\
df & 1 & 1 & 1 & 1 & 1 \\
Asymp. Sig. & .748 & .857 & .883 & .115 & .029 \\
\hline
\end{tabular}

a. Kruskal Wallis Test

b. Grouping Variable: sex/gender

The corresponding $\mathrm{p}$ - value of the test statistic for the only Budget has been observed to be 0.029 which is less than 0.05. It can thus be concluded that there is no difference between the Infrastructure Technical Expertise, Regulatory Committee, except for the Budget, where the people who are below 30 years encounter more challenges than other age groups. This can be explained that lack of Budget, as a challenge, is primarily considered by the people who are below 30 years as the mean rank of 69.99 which is lower than the mean rank of other age group. 
INTERNATIONAL JOURNAL OF ACADEMIC RESEARCH IN BUSINESS AND SOCIAL SCIENCES Vol. 10, No. 2, Feb, 2020, E-ISSN: 2222-6990 @ 2020 HRMARS

\section{Reliability Test}

Reliability Statistics

\begin{tabular}{|l|l|}
\hline Cronbach's Alpha & N of Items \\
\hline 653 & 5 \\
\hline
\end{tabular}

A total of 150 questionnaires were distributed and all were filled and returned giving a response rate of $100 \%$. Here the value of Cronbach's Alpha is 0.653 which indicates the internal consistency of our data. Our calculated value of Alpha is greater than 0.5 so the internal consistency is acceptable.

\section{Coefficients Test}

Coefficients $^{\text {a }}$

\begin{tabular}{|c|c|c|c|c|c|c|}
\hline \multirow{2}{*}{\multicolumn{2}{|c|}{ Model }} & \multicolumn{2}{|c|}{ Unstandardized Coefficients } & \multirow{2}{*}{\begin{tabular}{|l}
$\begin{array}{l}\text { Standardized } \\
\text { Coefficients }\end{array}$ \\
Beta
\end{tabular}} & \multirow[b]{2}{*}{$\mathrm{t}$} & \multirow[b]{2}{*}{ Sig. } \\
\hline & & B & Std. Error & & & \\
\hline \multirow[t]{5}{*}{1} & (Constant) & 2.500 & .409 & & 6.107 & .000 \\
\hline & Infrastructure & .273 & .085 & .272 & 3.198 & .002 \\
\hline & Technical Expertise & .041 & .053 & .068 & .778 & .048 \\
\hline & $\begin{array}{l}\text { Regulatory } \\
\text { Committee }\end{array}$ & .016 & .081 & .017 & .201 & .041 \\
\hline & Budget & .072 & .042 & .144 & 1.712 & .089 \\
\hline
\end{tabular}

a. Dependent Variable: Asset Management Digitalization

Interpretation of coefficients: Asset Management Digitalization

Here $\mathrm{R}$ is the regression coefficient and the regression parameter $\mathrm{B}$ which we have to interpret. We consider Fixed Assets Management through Digitalization as dependent variable and we have four independent variables. Here the value $B$ are the 2.50 (intercept), 0.273 ( $1^{\text {st }}$ regression coefficient), $0.041\left(2^{\text {nd }}\right.$ regression coefficient), 0.016 ( $3^{\text {rd }}$ regression coefficient) and 0.072 (last regression coefficient).

One unit increase of $1^{\text {st }}$ (Infrastructure) regression coefficient when other coefficients are remaining constant then the average increase of dependent variable (Asset Management Digitalization) is 2.50 unit. This was evidenced by the $p$ value of 0.000 which is less than that of critical value (0.05). So, there is a correlation.

One unit increase of $2^{\text {nd }}$ (Technical Expertise) regression coefficient when other coefficients are remaining constant then the average increase of dependent variable (Asset Management Digitalization) is 2.50 unit. This was evidenced by the $p$ value of 0.002 which is less than that of critical value (0.05). So, there is a correlation

One unit increase of 3rd (Regulatory Committee) regression coefficient when other coefficients are 
INTERNATIONAL JOURNAL OF ACADEMIC RESEARCH IN BUSINESS AND SOCIAL SCIENCES

Vol. 10, No. 2, Feb, 2020, E-ISSN: 2222-6990 @ 2020 HRMARS

remaining constant then the average increase of dependent variable (Asset Management Digitalization) is 2.50 unit. This was evidenced by the $p$ value of 0.048 which is less than that of critical value $(0.05)$. So, there is a correlation

One unit increase of 4th (Budget) regression coefficient when other coefficients are remaining constant then the average increase of dependent variable (Asset Management Digitalization) is 2.50 unit. This was evidenced by the $p$ value of 0.089 which is less than that of critical value (0.05). So, there is a correlation 
INTERNATIONAL JOURNAL OF ACADEMIC RESEARCH IN BUSINESS AND SOCIAL SCIENCES Vol. 10, No. 2, Feb, 2020, E-ISSN: 2222-6990 @ 2020 HRMARS

\section{Correlations Test}

\begin{tabular}{|c|c|c|c|c|c|c|}
\hline & & $\begin{array}{l}\text { Asset } \\
\text { Managem } \\
\text { ent } \\
\text { Digitalizati } \\
\text { on }\end{array}$ & $\begin{array}{l}\text { Infrastruct } \\
\text { ure }\end{array}$ & $\begin{array}{l}\text { Technic } \\
\text { al } \\
\text { Expertis } \\
\text { e }\end{array}$ & $\begin{array}{l}\text { Regulatory } \\
\text { Committee }\end{array}$ & Budget \\
\hline \multirow{3}{*}{$\begin{array}{l}\text { Asset } \\
\text { Management } \\
\text { Digitalization }\end{array}$} & $\begin{array}{l}\text { Pearson } \\
\text { Correlation }\end{array}$ & 1 & $.338^{* *}$ & $.219^{* *}$ & $.161^{*}$ & $.242^{* *}$ \\
\hline & Sig. (2-tailed) & & .000 & .007 & .049 & .003 \\
\hline & $N$ & 150 & 150 & 150 & 150 & 150 \\
\hline \multirow[t]{3}{*}{ Infrastructure } & $\begin{array}{l}\text { Pearson } \\
\text { Correlation }\end{array}$ & $.338^{* *}$ & 1 & $.356^{* *}$ & $.308^{* *}$ & $.259^{* *}$ \\
\hline & Sig. (2-tailed) & .000 & & .000 & .000 & .001 \\
\hline & $\mathrm{N}$ & 150 & 150 & 150 & 150 & 150 \\
\hline \multirow[t]{3}{*}{$\begin{array}{l}\text { Technical } \\
\text { Expertise }\end{array}$} & $\begin{array}{l}\text { Pearson } \\
\text { Correlation }\end{array}$ & $.219^{* *}$ & $.356^{* *}$ & 1 & $.307^{* *}$ & $.342^{* *}$ \\
\hline & Sig. (2-tailed) & .007 & .000 & & .000 & .000 \\
\hline & $\mathrm{N}$ & 150 & 150 & 150 & 150 & 150 \\
\hline \multirow[t]{3}{*}{$\begin{array}{l}\text { Regulatory } \\
\text { Committee }\end{array}$} & $\begin{array}{l}\text { Pearson } \\
\text { Correlation }\end{array}$ & $.161^{*}$ & $.308^{* *}$ & $.307^{* *}$ & 1 & $.278^{* *}$ \\
\hline & Sig. (2-tailed) & .049 & .000 & .000 & & .001 \\
\hline & $N$ & 150 & 150 & 150 & 150 & 150 \\
\hline \multirow[t]{3}{*}{ Budget } & $\begin{array}{l}\text { Pearson } \\
\text { Correlation }\end{array}$ & $.242^{* *}$ & $.259^{* *}$ & $.342^{* *}$ & $.278^{* *}$ & 1 \\
\hline & Sig. (2-tailed) & .003 & .001 & .000 & .001 & \\
\hline & $N$ & 150 & 150 & 150 & 150 & 150 \\
\hline
\end{tabular}

*. Correlation is significant at the 0.05 level (2-tailed).

\section{Interpretation of Correlations Test}

The relationship among Fixed Assets Management through Digitalization and Infrastructure, Technical Expertise, Regulatory Committee, Budget is approximately good because the value of the coefficient is $0.338,0.219,0.161,0.242$. The Pearson correlation coefficient indicates that there was a positive and significant relationship between Fixed Assets Management through Digitalization and Infrastructure. This was evidenced by the $p$ value of 0.000 which is less than that of critical value 
INTERNATIONAL JOURNAL OF ACADEMIC RESEARCH IN BUSINESS AND SOCIAL SCIENCES

Vol. 10, No. 2, Feb, 2020, E-ISSN: 2222-6990 @ 2020 HRMARS

(0.05).

The relationship between Infrastructure and Technical Expertise is approximately good because the value of the coefficient is 0.356 .

The relationship between Infrastructure and Regulatory Committee is approximately good because the value of the coefficient is 0.308 .

The relationship between Infrastructure and Budget is approximately good because the value of the coefficient is 0.259 .

The relationship between Technical Expertise and Regulatory Committee is approximately good because the value of the coefficient is 0.307 .

The relationship between Technical Expertise and Budget is approximately good because the value of the coefficient is 0.342 .

The relationship between Regulatory Committee and Budget is approximately good because the value of the coefficient is 0.278 .

\section{Recommendations}

-Assets management must be digitalized as to provide accurate information on the actual book value of each classification of fixed assets.

-To adhere to international accounting standards framework of disclosure the net book value such assets management digitalization is essential.

-Introduction of training facilities on the industry benchmark of assets digitalization and application of various classification of fixed assets. Like high tech assets useful life determination as per IAS $16-$ Property Plant.

-Introduction of high rate of depreciation - that is accelerating depreciation rates to the assets which are subject to obsolescence in few years. As robotics engineering is used now in many assets so it cannot be depreciated in the usual manner as per IAS - 3-Depreciation.

- Proper and digitalized inventory mechanism should be introduced to safeguard the assets from abuse and misuse.

-E-fixed assets identification numbers to be introduced to trace each and all type of assets.

-Smart technology like application development to be done to keep the control on the movement of the fixed assets through SIM based GPRS tracking devices.

\section{Limitation of the Research}

Firstly, the collection of data had an issue as many employees were not so much aware of the ongoing assets digitalization system.

Secondly, the nature of conventional assets and high-techrobotics-oriented assets classification and appreciation is a big challenge as per international accounting standard.

Thirdly, the time bound framework.

Finally, most of the data are very classified and used here very cautiously.

\section{Conclusion}

In the digital economy, change is rapid and often unexpected. Technological and business model innovations are disrupting market dynamics, while economic and geopolitical uncertainty injects a whole new level of volatility into the business environment. Digital transformation is a more holistic 
view, in that it not only focuses on digitizing and digitalizing but also focuses on how to implement these changes throughout an organization. It engages the entire organization and the people that make up the company, rather than just the processes and the data that are part of the company.

On a more individual level, the results of this report may inform managers of the importance of understanding the technology are a fundamental part of the business that requires its strategy. The digital strategy is an iterative and forever changing process that has to be updated alongside the internal factors of the industry. It may also have implications for the organization's mentality towards internal factors concerning the technical systems. If the business is in a changing climate such as the current financial industry, then it is necessary to design systems that can change and adopt new functionality, without having to do a major architectural redesign of the systems.

This research provides overview about Digital Asset Management (DAM), Blockchain, and robotics besides other internal and external factors. As the implementation of IR4.0 growing day by day in all industry, this researches result can be used as a reference for digital implementation in asset management.

Future research could be to evaluate cases where digital transformation has already been conducted and see the results of such transformations. It would also give the possibility to assess the transformation process and the implications found during transformation. Furthermore, explanation about how did the digital strategy change from before, during, and after the digital transformation. Recommendation for future research is to think about the gathering of information when in regards to financial organisations. There is a significant amount of data to collect; however, it is essential to make sure that the data looked for is available and offered by the company. 
INTERNATIONAL JOURNAL OF ACADEMIC RESEARCH IN BUSINESS AND SOCIAL SCIENCES

Vol. 10, No. 2, Feb, 2020, E-ISSN: 2222-6990 @ 2020 HRMARS

\section{References}

Alkaabi, A. K. A. S., Karim, A. M., Hossain, M. I., \& Nasiruzzaman, M. (2019). Assets Digitalization: Exploration of Prospects with Better Control Implementation. International Journal of Academic Research in Business and Social Sciences, 9(5), 960-970.

Björling, M. E. (2015). Available at: https://mikaelbjorling.com/

Davenport, T. H., \& Westerman, G. (2018). Why so many high-profile digital transformations fail.

Essaides, N. (2019). The Effects of Digital Transformation on Internal Controls. Digitalist. https://www.digitalistmag.com/finance/2019/10/21/effects-of-digital-transformation-oninternal-controls-06201061

Gomber, P., Koch, J. A., \& Siering, M. (2017, July). Digital Finance and Fintech: current research and future research directions. Journal of Business Economics, 87 (5), 537-580. https://digital.di.se/artikel/sa-ska-storbankerna-mota-startup-hotet

Jonsdottir, F., Toivonen, O., Jaatinen, V., Utti, A., \& Lindqvist, R. (2017). Fintech in the nordics; a deloitte review.

Lee, I., \& Shin, Y. J. (2018). Fintech: Ecosystem, business models, investment decisions, and challenges. Business Horizons, 61 (1), 35-46.

Matt, C., Hess, T., \& Benlian, A. (2015). Digital transformation strategies. Business \& Information Systems Engineering, 57 (5), 339-343.

Moran, A. (2015). Managing agile: Strategy, implementation, organisation and people. Cham: Springer International Publishing.

Nilsson, T. (2016). Sº ska storbankerna möta startup-hotet. Retrieved 2018-06-10, from 